\title{
Bioactivity and effects of spraying interval of selected plant extracts for control of pre-flowering insect pests of watermelon (Citrulus lanatus[Thunb.] Matsum. \& Nakai)
}

\author{
Alao FATAI OLAITAN ${ }^{1}$, Adebayo THIMOTY ABIODUN ${ }^{1}$, Olaniran OLADELE ABIODUN ${ }^{1,2}$
}

Received March 28, 2020; accepted July 31,2020.

Delo je prispelo 28. marca 2020, sprejeto 31. julija 2020.

Bioactivity and effects of spraying interval of selected plant extracts for control of pre-flowering insect pests of watermelon (Citrulus lanatus[Thunb.] Matsum. \& Nakai)

Abstract: This experiment was conducted to determine the efficacy of plant extracts of Tephrosial vogelii Hook. f., Moringa oleifera Lam., Annona squamosa L. and cashew nut (Anacardium occidentale L.) at two intervals of spraying against major pre-flowering insect pests of watermelon. The results show that the effectiveness of each plant extracts depends on the interval of spraying. Plants sprayed at 7-day intervals had significantly less insect infestation when compared with that of 10-day interval of spraying. T. vogelii and M. oleifera had higher insecticidal efficacy than $A$. squamosa and cashew nut extracts but the applied plant extracts had the same insecticidal potential with Lambda-cyhalothrin against the observed insects during late planting season. Therefore, the plant extracts proved to be alternative to synthetic insecticide in the management of insect pests of watermelon at 7-day interval application sequence.

Key words: Tephrosial vogelii; Moringa oleifera; Annona squamosa: Annacadium occidentale; watermelon
Biološki učinki intervalov škropljenja $\mathrm{z}$ izvlečki izbranih rastlin za uravnavanje škodljivih žuželk vobdobju pred cvetenjem lubenice (Citrulus lanatus[Thunb.] Matsum. \& Nakai)

Izvleček: Namen poskusa je bil določiti učinkovitosti izvlečka izbranih rastlin (Tephrosial vogelii Hook. f., Moringa oleifera Lam., Annona squamosa L. , Anacardium occidentale L.)v dveh intervalih škropljenja na glavne škodljivce lubenice v obdobju pred cvetenjem. Rezultati kažejo, da je učinkovitost vsakega od rastlinskih izvlečkov odvisna od interval škropljenja. Rastline, ki so bile škropljene v 7-dnevnih intervalih so bile značilno manj okužene v primerjavi s tistimi, ki so bile škropljene v 10-dnevnih intervalih. Vrsti T. vogelii in M. oleifera sta imeli večjo insekticidno učinkovitost kot vrsti $A$. squamosa in Anacardium occidentale. Uporabljeni rastlinski izvlečki so imeli na opazovane žuželke med pozno rastno sezono enak insekticidni potencial kot lambda-cihalotrin. Rastlinski izvlečki so se izkazali kot dobra alternativa sintetičnim insekticidom pri uravnavanju škodljivcev na lubenici pri 7-dnevnih intervalih uporabe.

Ključne besede: Tephrosial vogelii; Moringa oleifera; Annona squamosa; Annacadium occidentale; lubenica

1 Ladoke Akintola University of Technology, Department of Crop and Environmental Protection, Ogbomoso, Oyo state, Nigeria

2 Corresponding author, e-mail: oaolaniran@lautech.edu.ng 


\section{INTRODUCTION}

Watermelon (Citrullus lanatus[Thunb.] Matsum. \& Nakai) belongs to the Cucurbitaceae family, which includes about 118 genera and 825 species (Dane and Liu, 2007). It originates from Kalahari and Sahara deserts in Africa (Schippers, 2000) and now found in tropical and subtropical climates worldwide. However, this crop has been cultivated for a long time in Africa and in the middle East and Egypt (Huhet al., 2008; Gichimuet al., 2009).

Watermelon is a major cucurbit crop, which accounts for $6.8 \%$ of the world area (second to tomato) devoted to vegetable production in 2005. A rough estimate of annual word value of watermelon exceeds \$ 15 billion (FAO, 2005).Report claims that watermelon is the most popular cucurbits, followed by cucumber and melon (FAO, 2006).In Nigeria, it is grown intensively in the northern region and bulk of it is produced from this agro-ecological zone (IITA, 2007). Recently, its cultivation has spread to the west and east of southern Nigeria. But yields from this region are generally low due to insect pest infestation (Alao and Adebayo, 2015). Insect pests such as Zonocerus variegatus L., 1758, Aulocophoral affinis D., 1835, Phyllotreta cruciferae (Goeze, 1777), Bactrocera cucurbitea (C., 1849) e.t.c have been implicated to have caused economic damage to this crop (Olaifa, 1987; Alwood, 1999; Alao, 2015).

In view of the aforementioned fact, control of pests becomes imperative. The use of synthetic insecticides to control the menace of this problem is a common practice among the majority of farmers in developing countries. Most of the farmers are not aware of the hazardous effects of these synthetic insecticides due to lack of education. In the last decade, entomologists and environmentalists have proposed for the use of plant extracts as alternative to the synthetic insecticides. However, most of these plants are abundant in the tropical region and have also medicinal value (Isman, 2006). The use of plant extracts in the management of field and stored product pests in the developing countries is a welcome development in the pest management program.Insecticides derived from plants have been reported as the credible alternative to synthetic insecticides (Alao and Adebayo, 2011). Unlike conventional insecticides, plants derived insecticides contain an array of chemical compounds, which act concertedly on both behavioral and physiological processes.

Tephrosia vogelii Hook $\mathrm{f}$. is a small leguminous shrub, which grows to a height of about three to four meters. It is a perennial shrub with flowers and pods. The plant is widely distributed in the tropical, sub-tropical and regions of the world (Al-Zahrani, 2007). T. vogelii is traditionally used for its inchthyotoxic, insecticidal and food parasitical properties (Ibrahimet al., 2000; Dzendaet al.,
2007; Qureshiet al., 2010).Moringa oleifera Lam. is a pantropical treespecies that is known by such regional names as benzolive, drumstick tree, kelor, marango, saijhan and sajna (Fahey, 2005). It is the most widely cultivated species of a monogeneric family, the Moringaceae, that is native to the sub-Himalayan tracts of India and Pakistan. It has become naturalized in many locations in the tropics and is widely cultivated in Africa, Ceylon, Thailand, Burma, Singapore, West Indies, Sri Lanke India, Mexico, Malabar, Malaysia and the Philippines (Fashey, 2005; Shukla et al., 2011).The Annonaceae is a large family of almost exclusively tropical trees and shrubs comprising about 130 general and 2300 species (Cronguist, 1993). Leatemia and Isman (2004) reported that plant parts of some species of this family have been used traditionally as insecticides.The soursop (Annona muricata L.), sweetsop (A. squamosa L.), langsat (Lansium domesticum Corr.) and Sandoricum koetijape (Burm. f.) Merr. are abundant species in the tropics (Isman, 2006). Cashew (Anacardium occidentale L.) belongs to the family Anacardiaceae. The plant is a native to North-Eastern Brazil, where it is called by its Portuguese name caju (the fruit) or cajueiro (the tree) (Varghese and Pundir, 1964). Cashew nut extracts contains a high proportion of phenolic compounds, anarcadic acid and cardole (Oparaeke et al., 2005; Olotuah and Ofuya, 2010; Mukhopadyayet al,2010).

\section{MATERIALS AND METHODS}

\subsection{STUDY SITE}

The field experiment was conducted in the cropping season of 2011 and 2012 at Ladoke Akintola University of Technology (LAUTECH) Teaching and Research Farm, Ogbomoso, Oyo State, Nigeria.This region is position on longitude $4^{\circ} 3^{\prime} \mathrm{E}$ and latitude $10^{\circ} 5^{\prime} \mathrm{N}$. The region climate is described as hot humid tropical falls in Southern Guinea Savannah of Nigeria with a mean temperature of $27^{\circ} \mathrm{C}$ and annual rainfall of $1400 \mathrm{~mm}$, marked with dry and wet seasons, characterized by a bi-modal rainfall pattern with peaks in July and September and a short period of harmattan in between the seasons.

\subsection{EXPERIMENTAL DESIGN AND MANAGE- MENT}

The experimental field was harrowed and ploughed once and thirty (30) plots were mapped out and each experimental plot size was $3 \mathrm{~m} \times 3 \mathrm{~m}$ with four plant stand rows. This experiment was arranged and demarcated in a randomized complete block design. There were six 
treatments with three replicates. Two to four watermelon seeds (sugar baby) were sowed per hole. Two weeks after planting, thinning was done to one plant per stand. Each plot contained four plant rows.

\subsection{PREPARATION OF PLANT EXTRACTS}

The plants species screened for insecticidal properties were leaves of $T$. vogelii, $M$. oleifera, seeds of $A$. squamosa and cashew nuts. All the plant materials were air dried for 3-4 days to reduce the moisture content except cashew nut, which was left to stay for more than three weeks. In order to prepare extract from each of them, the target plant parts were crushed separately in a wooden mortal with pestle. $500 \mathrm{~g}$ each of the paste material was weighed separately with the sensitive scale into 10-litre plastic bucket containing $1000 \mathrm{ml}$ of water. These were allowed to settle overnight and the aqueous suspensions were filtered through muslin cloth. The filtrate then served as stock solution for the experiment. $1000 \mathrm{ml}$ were measured from the stock solution. This method of preparation of crude extracts is in line with already established method by Alao and Adebayo (2011), however, each of the plant extract and synthetic insecticide were further diluted with $1000 \mathrm{ml}$ of water to achieve the same spraying volume for all the treatment.

\subsection{TREATMENT APPLICATION}

Application of plant extracts was done (i) as spray at 7-day intervals and five weekly observations were made (ii) or spray at 10-day intervals and four weekly observations were made. The synthetic insecticide lambda-cyhalothrin was applied once in a week at manufacture's recommended rate. The foliar application of the treatments was done early in the morning with hand-held sprayer of 2-litre capacity. Unsprayed plots were included.

\subsection{DATA COLLECTION}

Population densities of insect pests were counted visually from four plant stands in the two middle plant rows. The observed adult insects collected were taken to Insect Muzeum at University of Ibadan for the identification of the species.

Percentage of leaves defoliation: Estimation of rate of defoliated leaves were done 2 nd week after spraying and the leaves showing evidence of shot holes were considered as being damaged by the studied insects. This was done visually by counting the defoliated leaves and total num- ber of leaves from the four selected plant stands in the two middle plant rows. Percentage of defoliated leaves was determined using the formula described below:

$\%$ leaves damaged $=$ (total no. of leaves produced per plant - no. of undamaged leaves $) \times 100$

total number of leaves produced

Yield: Three months after planting, the matured fruits were harvested and weighed on the field with manual scale in kilogram $(\mathrm{kg})$, which was later calculated in tons per hectare $\left(\mathrm{t} \mathrm{ha}^{-1}\right)$.

\subsection{DATA ANALYSIS}

Data collected were subjected to analysis of variance (ANOVA) using randomized complete block design. Significant means were separated with Duncan Multiple Range Test at $5 \%$ probability. To normalize variances for all analyses, the numbers of insects were square-root transformed. However, insecticide efficacy was calculated using Abbott's formula:

Efficacy $=(\mathrm{CA}-\mathrm{TA} / \mathrm{CA}) \times 100$.

CA - The total number of the insect from the untreated plants

TA - The total number of the insect from the treated plants

\section{RESULTS}

\subsection{EFFECT OF INTERVAL OF SPRAYING OF IN- SECTICIDES ON Aulocophora africana Mon., 1855}

During early planting season, there was no significant difference $(p<0.05)$ in the efficacy of $M$. oleifera and T. vogelii at 7 days interval, but T. vogelii treated plots had significant lower $(p<0.05) A$. africana infestation than $M$. oleifera treated plots at 10 days interval. Meanwhile, the efficacy of $T$. vogelii was comparable with lambda-cyhalothrin at 7-day interval, but this observation contradicts what was observed at 10-day interval. During late planting, $M$. oleifera and $T$. vogelii had the same statistical effect $(p<0.05)$ on infestation at 7-day intervals, meanwhile $M$. oleifera significantly $(p<0.05)$ suppressed $A$. africana infestation as it was observed in lambda-cyhalothrin treated plots at 10-day interval. However, application of plant extracts at 7-day interval had significant effect $(p<0.05)$ on reduction $A$. africana infestation than that of 10-day interval (Table 1). 
Table 1: Effect of interval of spraying of insecticides on Aulocophora africana population

\begin{tabular}{|c|c|c|c|c|}
\hline & \multirow[b]{2}{*}{ Insecticides } & \multicolumn{2}{|c|}{ Spraying interval (days) } & \multirow[b]{2}{*}{ Efficacy (\%) } \\
\hline & & 7 & 10 & \\
\hline \multirow[t]{7}{*}{ Early Season } & Annona squamosa & $2.41 \pm 0.12^{\mathrm{bc}}$ & $2.60 \pm 0.18^{\mathrm{ab}}$ & 17.05 \\
\hline & Cashew nut & $2.54 \pm 0.15^{\mathrm{ab}}$ & $2.73 \pm 0.14^{\mathrm{ab}}$ & 12.75 \\
\hline & Control & $3.02 \pm 0.15^{\mathrm{a}}$ & $3.02 \pm 0.15^{\mathrm{a}}$ & - \\
\hline & Moringa oleifera & $1.95 \pm 0.12^{c}$ & $2.48 \pm 0.12^{\mathrm{abc}}$ & 26.65 \\
\hline & lambda-cyhalothrin & $1.39 \pm 0.26^{\mathrm{d}}$ & $1.39 \pm 0.26^{\mathrm{d}}$ & 54.00 \\
\hline & Tephrosia vogelii & $1.95 \pm 0.12^{\mathrm{c}}$ & $2.33 \pm 0.15^{\mathrm{bc}}$ & 29.15 \\
\hline & Spray interval (mean) & $2.21^{\mathrm{b}} \pm 0.15$ & $2.43^{\mathrm{a}} \pm 0.17$ & \\
\hline \multirow[t]{7}{*}{ Late Season } & Annona squamosa & $1.29 \pm 0.24^{\mathrm{bc}}$ & $1.76 \pm 0.19^{\mathrm{ab}}$ & 25.25 \\
\hline & Cashew nut & $1.74 \pm 0.23^{\mathrm{ab}}$ & $1.86 \pm 0.17^{\mathrm{a}}$ & 11.75 \\
\hline & Control & $2.04 \pm 0.12^{\mathrm{a}}$ & $2.04 \pm 0.12^{\mathrm{a}}$ & - \\
\hline & Moringa oleifera & $0.71 \pm 0.00^{\mathrm{d}}$ & $0.71 \pm 0.00^{\mathrm{d}}$ & 100.00 \\
\hline & lambda-cyhalothrin & $0.71 \pm 0.00^{\mathrm{d}}$ & $0.71 \pm 0.00^{\mathrm{d}}$ & 100.00 \\
\hline & Tephrosia vogelii & $0.71 \pm 0.00^{\mathrm{d}}$ & $1.17 \pm 0.22^{\mathrm{cd}}$ & 71.35 \\
\hline & Spray interval (mean) & $1.20^{\mathrm{a}} \pm 0.09$ & $1.37^{\mathrm{b}} \pm 0.12$ & \\
\hline
\end{tabular}

Means with the same superscript(s) along the column are not significantly different at $5 \%$ probability using DMRT.

\subsection{EFFECT OF INTERVAL SPRAYING OF INSECTI- CIDES ON COCCINELLA Septempunctata Lin., 1758}

Among the plant extracts, cashew nut extract had the least insecticidal effect on C. occidentallis at 7 and 10-day intervals during early planting season. None of the plant extracts showed comparable effect with lambda-cyhalothrin during early planting season. T. vogelii extract had the highest insecticidal potential when compared with other tested plant extract in the early planting season.

During late planting season, the tested plant extracts compete effectively with lambda-cyhalothrin at 7-day interval of spraying. This result is similar to what was observed at 10-day interval spraying except cashew nut extracts which had the highest $C$. occidentalis infestation among the treated plots (Table 2).

\subsection{EFFECT OF INTERVAL OF SPRAYING OF INSEC- TICIDES ON Monoleptas australis Dej., 1836.}

Application of $M$. oleifera had highest insecticidal efficacy (29.2\%), when compared with other plant extracts at 7 -day interval of spraying during early planting season, but there were no significant difference $(p<0.05)$ between the efficacy of $M$. oleifera and T. vogelii at 10-day intervals. At 10-day interval cashew nut treatment had the highest population density of Monolepta spp. when compared with other plant extracts treated plants during early planting season. During late planting season, there was no significant difference $(p<0.05)$ between treated plots and untreated plots.

\subsection{EFFECT OF SPRAYING INTERVALS ON RATE OF LEAF DEFOLIATION}

The results obtained showed that unprotected leaves were heavily attacked by the observed insects during both seasons, but the intensity of defoliation was higher in the early planting season than late planting season. During early planting season, plants sprayed with $T$. vogelii and $M$. oleifera at 7 and 10 days-intervals had significantly better $(p<0.05)$ protected leaves against the leaf feeding insects, when compared with other plant extracts.

\subsection{EFFECT OF SPRAYING INTERVALS ON YIELD $(\mathrm{t}$ $\mathrm{ha}^{-1}$ )}

Among the plant extracts applied, T. vogelii treated 
Table 2: Effect of interval of spraying of insecticides on Coccinela septempunctata population

\begin{tabular}{|c|c|c|c|c|}
\hline & \multirow[b]{2}{*}{ Insecticides } & \multicolumn{2}{|c|}{ Spraying interval (days) } & \multirow[b]{2}{*}{ Efficacy (\%) } \\
\hline & & 7 & 10 & \\
\hline \multirow[t]{7}{*}{ Early Season } & Annona squamosa & $2.26 \pm 0.17^{\mathrm{bcd}}$ & $2.79 \pm 0.15^{\mathrm{ab}}$ & 16.40 \\
\hline & Cashew nut & $2.55 \pm 0.00^{\mathrm{abc}}$ & $2.79 \pm 0.15^{\mathrm{ab}}$ & 11.60 \\
\hline & Control & $3.02 \pm 0.15^{\mathrm{a}}$ & $3.02 \pm 0.15^{\mathrm{a}}$ & - \\
\hline & Moringa oleifera & $2.12 \pm 0.00^{\mathrm{cd}}$ & $2.41 \pm 0.12^{\mathrm{bcd}}$ & 25.00 \\
\hline & Lambda-cyhalothrin & $1.39 \pm 0.26^{\mathrm{e}}$ & $1.39 \pm 0.26^{\mathrm{e}}$ & 54.00 \\
\hline & Tephrosia vogelii & $1.95 \pm 0.12^{\mathrm{d}}$ & $2.48 \pm 0.12^{\mathrm{abcd}}$ & 26.66 \\
\hline & Spray interval (mean) & $2.22^{\mathrm{b}} \pm 0.12$ & $2.48^{\mathrm{a}} \pm 0.16$ & \\
\hline \multirow[t]{7}{*}{ Late Season } & Annona squamosa & $0.71 \pm 0.00^{\mathrm{b}}$ & $0.90 \pm 0.24^{\mathrm{b}}$ & 73.20 \\
\hline & Cashew nut & $0.88 \pm 0.15^{\mathrm{b}}$ & $1.27 \pm 0.25^{\mathrm{ab}}$ & 36.00 \\
\hline & Control & $1.68 \pm 0.14^{\mathrm{a}}$ & $1.68 \pm 0.14^{\mathrm{a}}$ & - \\
\hline & Moringa oleifera & $0.71 \pm 0.00^{\mathrm{b}}$ & $0.88 \pm 0.15^{\mathrm{b}}$ & 73.80 \\
\hline & Lambda-cyhalothrin & $0.71 \pm 0.00^{\mathrm{b}}$ & $0.71 \pm 0.00^{\mathrm{b}}$ & 100.00 \\
\hline & Tephrosia vogelii & $0.71 \pm 0.00^{\mathrm{b}}$ & $0.90 \pm 0.24^{\mathrm{b}}$ & 73.20 \\
\hline & Spray interval (mean) & $0.90^{\mathrm{a}} \pm 0.05$ & $1.06^{\mathrm{a}} \pm 0.17$ & \\
\hline
\end{tabular}

Means with the same superscript(s) along the column are not significantly different at $5 \%$ probability using DMRT

Table 3: Effect of interval of spraying of insecticides on Monolepta spp. population

\begin{tabular}{|c|c|c|c|c|}
\hline & \multirow[b]{2}{*}{ Insecticides } & \multicolumn{2}{|c|}{ Spraying interval (days) } & \multirow[b]{2}{*}{ Efficacy (\%) } \\
\hline & & 7 & 10 & \\
\hline \multirow[t]{7}{*}{ Early Season } & Annona squamosa & $2.55 \pm 0.00^{\mathrm{abc}}$ & $2.97 \pm 0.11^{\mathrm{abc}}$ & 18.35 \\
\hline & Cashew nut & $2.73 \pm 0.19^{\mathrm{abc}}$ & $3.12 \pm 0.19^{\mathrm{ab}}$ & 13.45 \\
\hline & Control & $3.38 \pm 0.21^{\mathrm{a}}$ & $3.38 \pm 0.21^{\mathrm{a}}$ & - \\
\hline & Moringa oleifera & $2.18 \pm 0.19^{\mathrm{cd}}$ & $2.61 \pm 0.11^{\mathrm{abc}}$ & 29.15 \\
\hline & Lambda-cyhalothrin & $1.65 \pm 0.30^{\mathrm{d}}$ & $1.65 \pm 0.30^{\mathrm{d}}$ & 51.20 \\
\hline & Tephrosia vogelii & $2.41 \pm 0.17^{\mathrm{bcd}}$ & $2.65 \pm 0.22^{\mathrm{abc}}$ & 25.15 \\
\hline & Spray interval (mean) & $2.48^{\mathrm{b}} \pm 0.18$ & $2.73^{a} \pm 0.19$ & \\
\hline \multirow[t]{7}{*}{ Late Season } & Annona squamosa & $0.71 \pm 0.00^{\mathrm{a}}$ & $0.71 \pm 0.00^{\mathrm{a}}$ & 100.00 \\
\hline & Cashew nut & $0.71 \pm 0.00^{\mathrm{a}}$ & $0.71 \pm 0.00^{\mathrm{a}}$ & 100.00 \\
\hline & Control & $0.99 \pm 0.24^{\mathrm{a}}$ & $0.99 \pm 0.24^{\mathrm{a}}$ & - \\
\hline & Moringa oleifera & $0.71 \pm 0.00^{\mathrm{a}}$ & $0.71 \pm 0.00^{\mathrm{a}}$ & 100.00 \\
\hline & Lambda-cyhalothrin & $0.71 \pm 0.00^{\mathrm{a}}$ & $0.71 \pm 0.00^{\mathrm{a}}$ & 100.00 \\
\hline & Tephrosia vogelii & $0.71 \pm 0.00^{\mathrm{a}}$ & $0.71 \pm 0.00^{\mathrm{a}}$ & 100.00 \\
\hline & Spray interval (mean) & $0.76^{\mathrm{a}} \pm 0.04$ & $0.76^{\mathrm{a}} \pm 0.04$ & \\
\hline
\end{tabular}

Means with the same superscript(s) along the column are not significantly different at $5 \%$ probability using DMRT. 
Table 4: Effect of interval of spraying of insecticides on rate of leaf defoliation (\%)

\begin{tabular}{|c|c|c|c|c|}
\hline & \multirow[b]{2}{*}{ Insecticides } & \multicolumn{2}{|c|}{ Spraying interval (days) } & \multirow[b]{2}{*}{ Insecticides (Mean) } \\
\hline & & 7 & 10 & \\
\hline \multirow[t]{7}{*}{ Early Season } & Annona squamosa & $42.1 \pm 0.75^{\mathrm{cd}}$ & $48.9 \pm 0.61^{\mathrm{bc}}$ & $45.5^{\mathrm{bc}}$ \\
\hline & Cashew nut & $46.9 \pm 0.86^{\mathrm{bcd}}$ & $52.8 \pm 0.62^{\mathrm{ab}}$ & $49.9^{\mathrm{b}}$ \\
\hline & Control & $61.2 \pm 0.65^{\mathrm{a}}$ & $61.2 \pm 0.65^{\mathrm{a}}$ & $61.2^{\mathrm{a}}$ \\
\hline & Moringa oleifera & $39.1 \pm 0.81^{\mathrm{de}}$ & $45.0 \pm 0.80^{\mathrm{bcd}}$ & $42.1^{\mathrm{c}}$ \\
\hline & Lambda-cyhalothrin & $31.0 \pm 0.65^{\mathrm{e}}$ & $31.0 \pm 0.65^{\mathrm{e}}$ & $31.0^{\mathrm{d}}$ \\
\hline & Tephrosia vogelii & $39.1 \pm 0.81^{\mathrm{de}}$ & $45.0 \pm 0.80^{\mathrm{bcd}}$ & $42.1^{\mathrm{d}}$ \\
\hline & Spray interval (mean) & $43.3^{\mathrm{b}} \pm 0.76$ & $47.3^{a} \pm 0.69$ & \\
\hline \multirow[t]{7}{*}{ Late Season } & Annona squamosa & $28.8 \pm 0.65^{\mathrm{abcd}}$ & $37.2 \pm 0.62^{\mathrm{ab}}$ & $33.0^{\mathrm{abc}}$ \\
\hline & Cashew nut & $33.2 \pm 0.00^{\mathrm{abc}}$ & $36.9 \pm 1.02^{\mathrm{ab}}$ & $35.1^{\mathrm{bc}}$ \\
\hline & Control & $43.1 \pm 0.61^{\mathrm{a}}$ & $43.1 \pm 0.61^{\mathrm{a}}$ & $43.1^{\mathrm{a}}$ \\
\hline & Moringa oleifera & $23.9 \pm 0.72^{\mathrm{bcd}}$ & $33.0 \pm 0.84^{\mathrm{abc}}$ & $28.4^{\mathrm{bc}}$ \\
\hline & Lambda-cyhalothrin & $15.0 \pm 1.23^{\mathrm{d}}$ & $15.0 \pm 1.23^{\mathrm{d}}$ & $15.0^{\mathrm{d}}$ \\
\hline & Tephrosia vogelii & $17.7 \pm 1.31^{\mathrm{cd}}$ & $28.8 \pm 0.65^{\mathrm{abcd}}$ & $23.3^{\mathrm{d}}$ \\
\hline & Spray interval (mean) & $26.9^{\mathrm{a}} \pm 0.75$ & $32.3^{\mathrm{a}} \pm 0.83$ & \\
\hline
\end{tabular}

Means with the same superscript(s) along the column are not significantly different at $5 \%$ probability using DMRT.

Table 5: Effect of interval of spraying of insecticides on melon yield ( $\left.\mathrm{t} \mathrm{ha}^{-1}\right)$

\begin{tabular}{|c|c|c|c|c|}
\hline & \multirow[b]{2}{*}{ Insecticides } & \multicolumn{2}{|c|}{ Spraying interval (days) } & \multirow[b]{2}{*}{ Yield $\left(\mathrm{t} \mathrm{ha}^{-1}\right)$} \\
\hline & & 7 & 10 & \\
\hline \multirow[t]{7}{*}{ Early Season } & Annona squamosa & $17.0 \pm 0.79^{\mathrm{bcd}}$ & $13.3 \pm 0.68^{\mathrm{bcd}}$ & $15.2^{\mathrm{b}}$ \\
\hline & Cashew nut & $20.8 \pm 0.94^{\mathrm{bc}}$ & $11.7 \pm 0.72^{\mathrm{cd}}$ & $16.3^{\mathrm{b}}$ \\
\hline & Control & $7.67 \pm 0.53^{d}$ & $7.67 \pm 0.53^{d}$ & $7.67^{c}$ \\
\hline & Moringa oleifera & $20.8 \pm 0.94^{\mathrm{bc}}$ & $13.8 \pm 0.61^{\mathrm{bcd}}$ & $17.3^{\mathrm{b}}$ \\
\hline & Lambda-cyhalothrin & $30.7 \pm 0.48^{\mathrm{a}}$ & $30.7 \pm 0.48^{\mathrm{a}}$ & $30.7^{\mathrm{a}}$ \\
\hline & Tephrosia vogelii & $22.2 \pm 0.95^{\mathrm{ab}}$ & $15.0 \pm 0.76^{\mathrm{bcd}}$ & $18.6^{\mathrm{b}}$ \\
\hline & Spray interval (mean) & $19.9^{\mathrm{a}} \pm 0.77$ & $15.4^{\mathrm{b}} \pm 0.63$ & \\
\hline \multirow[t]{7}{*}{ Late Season } & Annona squamosa & $16.7 \pm 0.80^{\mathrm{bc}}$ & $11.0 \pm 0.63^{\mathrm{bc}}$ & $13.9^{\mathrm{bc}}$ \\
\hline & Cashew nut & $15.3 \pm 0.96^{\mathrm{bc}}$ & $8.60 \pm 0.59^{c}$ & $12.0^{\mathrm{bc}}$ \\
\hline & Control & $8.33 \pm 0.57^{c}$ & $8.33 \pm 0.57^{c}$ & $8.33^{\mathrm{c}}$ \\
\hline & Moringa oleifera & $18.8 \pm 0.56^{\mathrm{ab}}$ & $12.0 \pm 0.44^{\mathrm{bc}}$ & $15.4^{\mathrm{b}}$ \\
\hline & Lambda-cyhalothrin & $26.7 \pm 0.57^{\mathrm{a}}$ & $26.7 \pm 0.57^{\mathrm{a}}$ & $26.7^{\mathrm{a}}$ \\
\hline & Tephrosia vogelii & $18.03 \pm 1.08^{\mathrm{ab}}$ & $11.8 \pm 0.58^{\mathrm{bc}}$ & $14.9^{b}$ \\
\hline & Spray interval (mean) & $17.3^{\mathrm{a}} \pm 0.76$ & $13.1^{\mathrm{b}} \pm 0.56$ & \\
\hline
\end{tabular}

Means with the same superscript(s) along the column are not significantly different at $5 \%$ probability using DMRT. 
plants produced the highest yield $\left(22.2 \mathrm{t} \mathrm{ha}^{-1}\right)$ followed by $M$. olefera treated plots in the early planting season at 7-day intervals during early planting season. There was no significant difference $(p<0.05)$ between the plots sprayed with T. vogelii and $M$. oleifera at 10-day intervals in respect to yield.

However, significant higher yield was obtained from the plots sprayed with $T$. vogelii and $M$. oleifera at 7-day intervals during late planting season but yield obtained from $A$. squamosa treated plots was significantly the same as the yield obtained from M. oleifera and T. vogelii treated plots.

\section{DISCUSSION}

The level of insect infestation determines the efficacy of the applied insecticides. This experiment revealed that the protected plants had lower insect infestation than unprotected plants. This is an indication that plants sprayed with $T$. vogelii, $M$. oleifera, A. squamosa and C. occidentale extracts had significant insecticidal action in the control of Monolepta spp., A. africana and C. occidentalis. However, the insecticidal potential exhibited by these plant extracts can be attributed to the insecticidal active compounds isolated from each tested plant extracts. Rotenone has been reported by Neuwinger (2004), Sileshetal. (2005), Nyirendaet al. (2010) as insecticidal compound isolated from $T$. vogelii. Rotenone has also been described as a mitochondria poison, which blocks the electron transport chain and prevents energy production (Hollingsworth et al., 1994). Research has shown that quercetin and kaempferol derived from $M$. oleifera have been reported as insecticidal compounds (Pace-Asciak et al., 1995). The efficacy of $M$. oleifera in the control of field and stored products insect pests has been reported (Alao and Adebayo, 2015; Babarinde et al., 2013; Ileke and Olotuah, 2012). Acetenogins and anacardic acid reportedly isolated from $A$. squamosa and $A$. occidentalium respectively were also found to be effective against insect pests infestations (Olotuah and Ofuya, 2010; Oparaeke and Olubunmi, 2006).

The data suggest that the effectiveness of each test plant extracts depends on the interval of spraying. Plant sprayed at 7-day interval of spraying had higher efficacy against the observed insects than that of 10-day spraying interval. This suggests that environmental factors such as wind and sunlight reduce the potency of the applied plant extracts through degradation (Eileen and Sydney, 2013) meaning that the longer the plant extracts stay on the plant the easier the reduction in the insecticidal potential. This characteristic nature of the plant extracts is the major limitation of the plant extract as an insecticide (Isman, 2006). Based on this, botanical insecticides are not true insecticide, but they form a basis for the formulation of new synthesized insecticides, which are environmentally friendly to our farmers, consumers as well as beneficiary insects such as bees.
These results suggest that plant extracts were not effective as synthetic insecticide (lambda-cyhalothrin). This can be attributed to the photostability nature of the synthetic insecticide used. This showed that consumption of the synthetic insecticide treated fruits may have negative health impact on the human health. This may likely boost the economy of our poor resource farmers, because of their availability of the tested plant extracts. However, the preparation of plant-based insecticides does not call for any technicality.

Yield has been reported as the ultimate goal of farmers, but insect pests infestations have been described as the major factor that hindered the hope of resource farmers (Alao, 2015). Yield obtained from the plots sprayed at 10-day intervals was significantly lower compared with the yield obtained from the plots sprayed at 7-day intervals. This might have been due to significant higher level of insects attacked on the plants sprayed at 10-day intervals. This also suggest that the observed insect contribute negatively to the yield of watermelon.Lambda-cyhalothrin had higher insecticidal efficacy against insect infestations, when compared with plant extracts during early planting season. This can be attributed to photostability nature of synthetic pyrethroid (Pedigo and Rice, 2014). However, the efficacy of plant extracts as insecticides was comparable with lambda-cyhalothrin during late planting season, this is due to low level of insect infestation observed during the late planting season.

\section{CONCLUSION}

This experiment shows that plant extracts can be used in the management of insect pests of watermelon. Meanwhile, T. vogelii and $M$. oleifera exhibited higher insecticidal potential than A. squamosa and A. occidentalis. The tested plant extracts had short lasting insecticidal effects when compared with lambda-cyhalothrin, which actually killed the observed insects. This delayed effect is the major characteristic of botanical insecticides Isman, 2008). Any of these plants extracts can be applied at 7-day intervals. The use of plant extracts in the management of field and stored product pests in the developing countries will be a welcome development in the pest management program.

\section{REFERENCES}

Alao F.O., Adebayo, T.A. (2011). Comparative toxicity of botanical and synthetic insecticides against major field insect pests of cowpea (Vigna unguiculata(L.) Walp.). Journal of Natural Product and Plant Resources, 1(3), 86-95.

Allwood A.J., Chinajariyawong A., Drew R.A.I., Hamacek E.L., 
Hancock D.L., Hengsawad C., Kristaneepaiboon S., Leong C.S.T., and Vijansegaran S. (1999). Host plant record of fruitflies (Diptera; Tephritidae) in southeast Asia. The Raffles Bulletin in zoology supplies. 7, 92pp.

Al-Zahrani R.M. (2007). Systematic study of the genus Tephrosia Pers. (Fabaceae) in Saudi Arabia. Post graduate thesis.

FAO (2005). FAO STAT: Available at http:/faostat.fao.org

FAO (2006). FAO STAT Agriculture Data. [Internet] Http:// apps.fao.org/page/collections?subset=agriculture. Accessed

Cronquist A.C. (1993). An integrated system of classification of flowering plants. Columbia University Press. New York, NV

Dane F., Liu J. (2007). Diversity and origin of cultivated and citron type watermelon (Citrullus lanatus). Genetic Resources and Crop Evolution, 54, 1255-1265. https://doi.org/10.1007/ s10722-006-9107-3

Eileen A.B., Sydney G.P. (2013). Natural Products for Managing Landscaping and Garden Pests in Florida. EDIS.

Fahey J.W. (2005). Moringa oleifera: A review of the medical evidence for its nutritional, therapeutic, and prophylactic properties. Part 1. Trees Life J., 1:5 (http://www.ttljournal. org/images/articles/20051201124931586_3.pdf).

Gichimu B.M., Owuor B.O., Mwai G.N., Dida, M.M. (2009). Morphological characterization of some wild and cultivated watermelon (Citrullus sp.) accession in Kenya. ARPN Journal of Agricultural and Biological Science, 4, 1990-6145.

Huh, Y.C. (2008). Morphological characterization of Korean and Turkish watermelon germplasm. Cucurbitaceae. Proceedings of the $9^{\text {th }}$. EUCARPIA meeting on genetics and breeding of Cucurbitaceae (Pitrat M. Ed.), INRA, Avignon, France. May 21- 24.

Hollingworth R.M., Ahmmadsahib K.L., Gadelhak G., McLaughlin J.L. (1994). Inhibitors of complex I in the mitochondrial electron transport chain with activities as pesticides. Biochemical Society Transactions, 22, 230-233. https://doi.org/10.1042/bst0220230

Ibrahim B., M’batchi B., Mounzeo H., Bourobou HP., Passo P. (2000). Effect of Tephrosia vogelii and Justicia extensa on tilapia nilotica in vivo. Journal of Ethnopharmacology, 69, 99-104. https://doi.org/10.1016/S0378-8741(99)00036-7

Isman, M.B. (2006). Botanical insecticides, deterrents and repellents in modern agriculture and increasingly regulated world. Annual Review of Entomology, 51, 45-66. https://doi. org/10.1146/annurev.ento.51.110104.151146

Leatemia J.A., Isman M.B. (2004). Insecticidal activity of crude seed extracts of Annona spp., Lansium domesticum and Sandoricum koetjape against lepidopteran larvae. Phytoparasitica, 32(1), 30-37. https://doi.org/10.1007/BF02980856

Mukhopadhyay A.K., Hati A.K., Tamizharasu W., Satyababu P.
(2010). Larvicidal properties of cashew nut shell liquid (Anarcardium occidentale L.) on immature stages of two mosquito species. Journal of Vector Borne Diseases, 47, 257-260.

Neuwinger H. D. (2004). Plants used for poison fishing in tropical Africa. Toxicon, 44, 417-430. https://doi.org/10.1016/j. toxicon.2004.05.014

Nyirenda S.P., Sileshi G., Belmain S.R., Kamanula J.F., Mvumi B., Sola P., Nyerenda G.K.C., Stevenson P.C. (2011). Farmers ethno-ecological knowledge of vegetable pests and their management using pesticidal plants in northern Malawi and Eastern Zambia. African Journal of Agricultural Research, 6, 1525-1537.,

Opareake A.M., Bunmi B. (2006). Insecticidal potential of cashew (Anacardium occidentale L.) for control of the beetle, Callosobruchus subinnotatus (Pic, 1914) (Bruchidae) on bambara groundnut (Voandzeia subterranea L.). Archives of Phytopathology and Plant Protection, 39(4), 247 - 251. https://doi.org/10.1080/03235400500094431

Pace-Asciak C.R., Hahn S., Diamandis E.P., Soleas G., Goldberg D.M. (1995). The red wine phenolics transresveratrol and quercetin block human platelet aggregation in eicosanoid synthesis: Implication for protection against coronary heart disease. Clinica Chimica Acta-Journal, 235(2), 207-219. https://doi.org/10.1016/0009-8981(95)06045-1

Qureshi R., Bhatti G.R., Memon R.A., (2010). Ethnomedicinal uses of herbs from northern part of Nara desert, Pakistan. Pakistan Journal of Botany, 42, 839-851.

Schippers, R.R. (2000). African indigenous vegetable, pp: $56-$ 60. An overview of the cultivated species chatthan, U.K RN. RACO, EU.

Silesh G., Mafongoya P.L., Kwesiga F., Nkunika P. (2005). Termite damage to maize grown in agro forestry systems; traditional fallows and monoculture on nitrogen-limited soils in eastern Zambia. Agriculture Forest Entomology, 7, 6169. https://doi.org/10.1111/j.1461-9555.2005.00242.x

Oltuah O.F., Ofuya T.I. (2010). Comparative protection of cowpea, Vigna unguiculata, (L.) Walpers against field insect pests using Cashew nut shell liquid and Cypermethrin (Cymbush). Pakistan Journal of Nutrition, 9(2), 158161. https://doi.org/10.3923/ pjn.2010.158.161

Varghese T., Pundir Y. (1964). Anatomy of the pseudocarp in Anacardium occidentale L. Proceedings of the Indian Academy of Plant Sciences-Section B, 59, 252-258.

Shukla A. (2011). The magic remedy of Oleifera: overview. International Journal of Biomedical and Advance Research, 2(05). https://doi.org/10.7439/ijbar.v2i6.35 